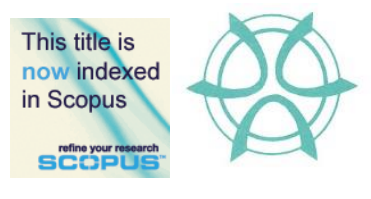

PLANNING MALAYSIA:

Journal of the Malaysian Institute of Planners

VOLUME 16 ISSUE 2 (2018), Page 1 - 11

\title{
TOWARDS AN ISLAMIC APPLICATION OF VISUAL PRIVACY PRINCIPLES ON MALAYSIAN TERRACE HOUSING: A CONCEPTUAL FRAMEWORK
}

\author{
Azhani Abd Manaf ${ }^{1}$, Zaiton Abdul Rahim ${ }^{2}$, Noor Hanita Abdul Majid ${ }^{3}$, \& \\ Spahic Omer ${ }^{4}$ \\ 1,2,3 Kulliyyah of Architecture and Environmental Design \\ ${ }^{4}$ Kulliyyah of Islamic Revealed Knowledge and Human Sciences \\ INTERNATIONAL ISLAMIC UNIVERSITY MALAYSIA
}

\begin{abstract}
This paper proposes a conceptual framework illustrating the application of Muslim Visual Privacy (MVP) of terrace housing by Malay occupants living in urban areas of Malaysia. Malay occupants are central to this study due to their specific views and requirements on visual privacy defined by religion and cultural norms. The study employs a thorough analysis of empirical data and review of past literatures in order to discuss vital and relevant theories. The findings of this study suggested a conceptual framework incorporating the sources of MVP elements as well as other important variables influencing the Malay Muslim occupants in terms of how they apply, regulate and modify the visual privacy levels in their respective terrace houses. The proposed framework might only represent a small portion in the entire effort, nevertheless it remains a significant contribution towards arriving at a more valid definition of MVP for Malay occupants in terrace housing. A clearer definition will then assist architects, developers as well as home owners' themselves in terms of how they design and manipulate physical elements of the house to achieve more functional visual privacy levels as per religious requirements.
\end{abstract}

Keywords: Malay, terrace house, Malaysia, Muslim Visual Privacy, Islamic, conceptual framework 
Azhani Abd Manaf, Zaiton Abdul Rahim, Noor Hanita Abdul Majid, \& Spahic Omer

Towards an Islamic Application of Visual Privacy Principles on Malaysian Terrace Housing: A Conceptual Framework

\section{INTRODUCTION}

There is a consensus in literature that each culture approaches privacy differently, although it is a common need across all cultures (Rapoport, 1969; Newell, 1995). This issue was further discussed by Altman (1977) on the differing methods and perception of various cultures regarding privacy regulations. Noorul Huda \& Anwar (2013) in their study suggest that a proper application of religious beliefs, one of the main aspects being privacy, will enhance the overall quality of life and home. Islam placed the highest importance on visual privacy due to its direct impact on physical elements of the traditional Islamic city (Hakim, 2008).

Past studies defined visual privacy differently depending on the focus and issues of the studies. However, the studies ultimately relate back to the same point which is the visual permeability of a space or building (Hakim, 2008; Mortada, 2003; Reis \& Lay, 2004; Shach-Pinsly, Fisher-Gewirtzman, \& Burt, 2011). Most scholars tend to define them from the built environment's perspective. Thus they use terms 'visual corridors' (Hakim, 2008), 'visual integration' and 'control of visual connections' (Shach-Pinsly et al., 2011). The terms are mostly in reference to the visual line of sight created by the built environment and is independent of who is looking (person inside or outside), or the morale behind it.

\section{THEORETICAL REVIEW}

\section{A Visual Privacy - Definition and Factors}

The study by Reis and Lay (2004) defines visual privacy as what is visualized from a single point of view in a particular space (viewing angle and distance), and internal visual privacy regulation as controlling extent of visual integration; that is to block or allow visual connections. On the other hand, Shach-Pinsly et al. (2011) define visual privacy as an optimization process of controlling the level of visual exposure and visual openness. The definition is closer to Altman's (1977) definition of privacy regulation which described privacy as an open-close system to attain the optimum amount of privacy required specific to each individual's needs.

Furthermore, Bahammam (1998) outlines the roles of spaces, houses, street, and neighbourhood as contributing towards the overall visual privacy of the house environment. Visual privacy is the decisions which contribute towards visual separation between different sections and elements within the home, between the home and the street, and between dwelling units. The above suggestions, although clear in its own way, appears to be lacking certain morale or humanistic perspective which should be included, as behavioural mechanism is also a major component of visual privacy regulator other than the physical elements.

Altman and Chemers (1987), Zimring et al. (1978), Margulis (1974) and Al-Kodmany (1996) as cited by Abbasoglu and Dagli (n.d.) emphasize that any variable or sub-variable could be the focus of study in environment-behaviour 
research, which in this study focuses on visual privacy. Review of literature presents the independent and dependent variables with regards to visual privacy as summarized in Table 1. Among the main focus of the studies were to analyze residential visual privacy and factors affecting it. Most studies take a general stance on privacy, thus there are still not many works of literature available exploring visual privacy specifically. Nonetheless, a general picture regarding the concept and factors affecting residential visual privacy has begun to take shape.

\section{Visual Privacy from Islamic Prespective}

Privacy of the family in the house is of great importance in Islam as it is the sole right of the home owners to be able to rest his body and mind and to be happy within that space (Al-Kodmany, 1999; Hakim, 2008; Omer, 2010). Based on Sharia principles, Islamic scholars asserted that visual privacy is defined as the protection of the individual's awrat from the eyes of strangers (non-mahram) (Mortada, 2003), with a secondary goal of protecting the modesty of the family (Mortada, 2003; Omer, 2004) and lastly, fulfilling the rights of the neighbours to theirs (Hakim, 2008; Omer, 2004).

Table 1: Empirical analysis of visual privacy

\begin{tabular}{|c|c|c|c|}
\hline Author, year & Place of origin & Dependent variable & Independent variables \\
\hline Saleh (1998) & Saudi Arabia & $\begin{array}{l}\text { Physical built } \\
\text { environment }\end{array}$ & $\begin{array}{l}\text { Visual privacy and communal } \\
\text { socialization on physical built } \\
\text { environment }\end{array}$ \\
\hline $\begin{array}{l}\text { Brown \& } \\
\text { Altman (1983) }\end{array}$ & USA & Residential burglary & $\begin{array}{l}\text { - territorial markers } \\
\text { - visual access }\end{array}$ \\
\hline $\begin{array}{l}\text { Reis \& Lay } \\
(2004)\end{array}$ & Brazil & $\begin{array}{l}\text { Internal visual } \\
\text { privacy }\end{array}$ & $\begin{array}{l}\text {-visual and functional } \\
\text { connections between the spaces } \\
\text {-isovist area or visual field } \\
\text { produced from the center of } \\
\text { common area. }\end{array}$ \\
\hline Sipahi (2016) & Turkey & $\begin{array}{l}\text { External Visual } \\
\text { privacy (visual } \\
\text { privacy of windows } \\
\text { only) }\end{array}$ & $\begin{array}{l}\text { Right to a view (visual access) } \\
\text { and right to be protected from } \\
\text { visual overlooking (visual } \\
\text { exposure). }\end{array}$ \\
\hline $\begin{array}{l}\text { Abdul Rahim } \\
(2015)\end{array}$ & Malaysia & $\begin{array}{l}\text { Visual privacy } \\
\text { (definition, regulation } \\
\text { and modification) }\end{array}$ & Religion and culture \\
\hline $\begin{array}{l}\text { Abbasog-lu \& } \\
\text { Dagli (n.d.) }\end{array}$ & $\begin{array}{l}\text { Famagusta, } \\
\text { Cyprus }\end{array}$ & $\begin{array}{l}\text { Women's visual } \\
\text { privacy }\end{array}$ & Architectural elements \\
\hline $\begin{array}{l}\text { Shach-Pinsly et } \\
\text { al. (2011) }\end{array}$ & $\begin{array}{l}\text { Non-Muslim / } \\
\text { Israel }\end{array}$ & $\begin{array}{l}\text { Visual privacy in } \\
\text { general }\end{array}$ & $\begin{array}{l}\text { Desired privacy and achieved } \\
\text { privacy (optimization model) }\end{array}$ \\
\hline $\begin{array}{l}\text { Bermanian \& } \\
\text { Saremi (2015) }\end{array}$ & Iran & $\begin{array}{l}\text { Visibility } \\
\text { characteristics of } \\
\text { physical built } \\
\text { environment } \\
\text { (external- windows } \\
\text { only) }\end{array}$ & $\begin{array}{l}\text { Visual exposure, and visual } \\
\text { openness }\end{array}$ \\
\hline
\end{tabular}


Azhani Abd Manaf, Zaiton Abdul Rahim, Noor Hanita Abdul Majid, \& Spahic Omer

Towards an Islamic Application of Visual Privacy Principles on Malaysian Terrace Housing: A Conceptual Framework

\begin{tabular}{|c|c|c|c|}
\hline Ayman (2011) & Jordan & $\begin{array}{l}\text { Residential } \\
\text { satisfaction of visual } \\
\text { privacy }\end{array}$ & $\begin{array}{l}\text { - Current perception, } \\
\text { - satisfaction of building } \\
\text { elements, } \\
\text { - privacy regulation methods, } \\
\text { - space usage pattern } \\
\text { - house modification }\end{array}$ \\
\hline $\begin{array}{l}\text { Shabani et al. } \\
(2010)\end{array}$ & Iran & $\begin{array}{l}\text { Privacy (including } \\
\text { visual privacy) level } \\
\text { in modern housing }\end{array}$ & $\begin{array}{l}\text { Flexibility patterns (between } \\
\text { modern pattern to pattern based } \\
\text { on privacy levels) }\end{array}$ \\
\hline $\begin{array}{l}\text { Kennedy, Buys } \\
\text { \& Miller } \\
(2015)\end{array}$ & Brisbane & $\begin{array}{l}\text { Overall residential } \\
\text { satisfaction }\end{array}$ & $\begin{array}{l}\text { Factors related to visual } \\
\text { exposure (visual privacy) and } \\
\text { visual access (access to } \\
\text { sunlight and view) }\end{array}$ \\
\hline
\end{tabular}

The three levels of privacy which can be extracted from the definition are; 1) the privacy of the individual awrat from non-mahram, 2) the privacy of the daily life of the family and 3) the rights of the neighbours to their privacy. Muslim scholars tend to define visual privacy through a more humanistic angle (Mortada, 2003; Abdul Rahim, 2007; Hakim, 2008; Abdul Rahim, 2008). Hakim (2008) and Mortada (2003) for example, definevisual privacy as protecting the family members especially the females from the unsolicited views of the nonmahram. The Islamic definition usually refers to the extent of the human body and the family relation. The human body refers to the extent of awrat as defined by Quran and Sunnah and non-mahram refers to strangers who are outside of the family nucleus (Mortada, 2003). Ayman (2011) on the other hand defines visual privacy as freedom to carry out daily routines free from observation of neighbours and passers-by.

These definitions of visual privacy were dependent on whom the visual intrusion is blamed on, the part of body which can be seen, one's position in the family (ie. in the nucleus or larger family circle?) and moral dimensions. The perspectives indicate that there is a need for a more comprehensive definition for visual privacy from Islamic perspective which takes into account the important factor of visual access as well.

An important study was done by Hakim (2008) whom framework outlined the static and dynamic variables pertinent to the shaping of Islamic urban built environment. The study referred to Shariah principles as static, while Islamic urf' as dynamic factor. Urf' are local cultural norms which are important factors in analyzing the application of visual privacy by a specific local Muslim community.

\section{Culture and Visual Privacy of Housing from Islamic Perspective}

Islamic architecture is distinct from others due to the application of value system and custom (urf') relating to built environment. Islamic scholars refer to Surah 7:199 of the Quran in explaining the nature of urf' which can be translated as 
"Take things at the face value, and bid to what is customary (or accepted by local tradition), and turn away from the ignorant." Hakim (1994) defines urf' as custom or a habit, provides a unifiying and diversifying factor to the housing of Muslim societies in the world (Hakim, 1994, 2008; Mortada, 2003; Omer, 2004). Islamic scholars agreed that the factor which unites any Islamic built environment is a set of guiding principles (value system) which come from the same source that is Qur' an and Sunnah (Hakim, 1994; Mortada, 2003).

As these values and customs spreaded across Muslim communities in the world, the nature of the urf' may change to adapt to local culture and specific times and place (known as local urf') (Hakim, 1994; Mortada, 2003). However, the basic values and guiding principles based on Sharia remained, thus uniting Islamic built design despite of its local cultures (Hakim, 1994, 2008; Mortada, 2003). On the other hand, latent literature further described that diversity between built environments in Muslim communities are due to the dynamic nature of the urf' itself which is meant to be adapted to a particular time and place (Hakim, 1994; Mortada, 2003). The effect of the urf' is more obvious in small scale changes made by decisions of individual residents. For example how a resident in Saudi Arabia modifies his house to make it more privacy compliant (Hakim, 1994), which mainly consists of small changes to the physical urban form made based on unified agreements after discussions and dialogues sessions (Omer, 2004).

In this study, Sharia principles related to built environment is the unifying element of Muslim housing. On the other hand, culture and other non-cultural factors are the diversifying elements (local urf'). This is supported by ElShorbagy (2010) and Hakim (2008) whom both agree that each architectural element represents a solution to a problem which rises at a specific time. One of the main problems is to protect modesty (awrat) of the family in the house within the constraints of house construction of that time and place (Figure 1).

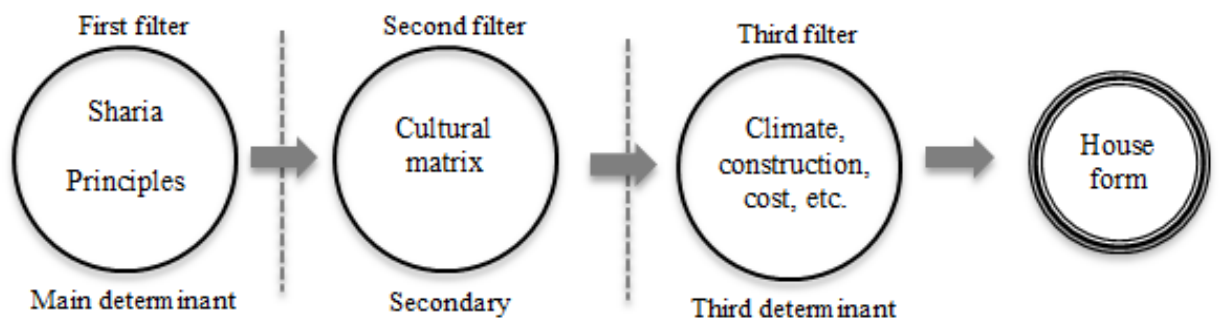

Figure 1: Factors influencing house form from Islamic perspectives

\section{Visual Privacy Regulations}

The field of regulating visual privacy of the house environment can best be explained by Altman's theory on privacy regulators. Altman (1977) theorizes that privacy regulators consist of three main mechanisms which are social, 
Azhani Abd Manaf, Zaiton Abdul Rahim, Noor Hanita Abdul Majid, \& Spahic Omer

Towards an Islamic Application of Visual Privacy Principles on Malaysian Terrace Housing: A Conceptual Framework

behavioural and environmental. Social mechanisms are instilled and governed by the cultural institutions. Social mechanisms consist of social supports and policy supports which are both dependent on accepted practices, mores, roles, and rules. The second is behavioural mechanism that includes cognitive and overt behaviours. Factors which interest this study are the territoriality markers which are expressed as personal space, verbal and nonverbal behaviours. These two factors directly influence the characteristics of physical elements of the house, which falls under the third mechanism namely the environmental mechanism, which affects visual privacy levels. Furthermore, Altman (1977) and Ozaki (2002) strongly suggest that effective privacy regulations require a mixture of mechanisms working as a system achieving the required visual privacy level.

House modification was placed under the third mechanism which is the environmental mechanism. Environmental mechanism was defined by Kupritz, (2000, p.50) as "the physical elements, devised or deployed by designers, to regulate privacy." Kupritz (2000) further explained that these physical elements function as apparatus used by individuals in controlling privacy levels. The physical elements are the lego blocks in constructing the required visual privacy levels and based on the frameworks, are directly affected by territoriality which is a behavioural mechanism. Therefore, physical elements of the house, other than being the elements proposed by designers in suggesting the "right" amount of visual privacy a house owner should have, are also territorial markers which a house owner can manipulate to achieve the "optimum" amount of visual privacy which they need.

\section{Visual Restriction and Visual Access}

This study describes visual restriction and visual access as main variables affecting visual characteristics of a house. Shahch-Pinsley et al. (2001) describe visual restriction, which they termed as exposure, as being a component of visual privacy but not fully representing visual privacy. The same study defined visual restriction as: "the visual penetration of one's privacy as a result of being viewed from the external spaces of other building facades or public spaces at street level" (Shahch-Pinsley et al., 2011, p.235). Meanwhile visual access, or openness, was defined as 3 aspects which are: 1) the measured length of built facades from which the view can be observed, 2) the measured area of built facades from which the view can be observed, and 3) the measured landscape area being viewed at street level and at every built storey (the isovist area) (Shahch-Pinsley et al., 2001). Additionally, visual restriction is related to negative intrusion, visual access on the other hand, has a positive connotation related to view.

This study highlights the importance of both visual restriction and visual access as factors of visual privacy. Review of traditional Islamic housing displayed the use of masyrabiyya or roshin, which reflects the need to allow visual access, mainly to allow female family members to view out, without being 
PLANNING MALAYSIA

Journal of the Malaysia Institute of Planners (2018)

viewed. Thus this study defines visual privacy of the house from Islamic perspective as the visual restriction of awrat and modesty of the family based on the requirements of Islamic principles while still allowing provision for visual access and its benefits.

\section{BACKGROUND}

According to Zulkeplee, Buys and Aird (2014) and El-Shorbagy (2010), Muslim houses came in a variety of forms and designs due to cultural diversity, yet unified by a few similar traits based on religious requirements. The traditional Malay house which is in line with said trend exudes sensitivity to socio-cultural and religious needs of the occupants. The terrace housing in Malaysia on the other hand, is a step backward, as it disregards the socio-cultural factors of its inhabitants.

Past studies by Abdul Rahim and Hashim (2008), Farah (2010) and Abdul Rahim (2008) highlight the lack of visual privacy encountered by Malay occupants of terrace housing in urban areas. Erdayu, Esmawee and Masran (2010 $\& 2012$ ) point out that conflicts due to incompatibility of the home environment and cultural norms termed as 'housing stress' may have adverse psychological effects on the occupants. This ultimately leads to changes in behavioural norms and abandonment of required religious and cultural values (Abdul Rahim \& Hashim, 2008; Farah, 2010). This study proposes the concept of MVP or Muslim visual privacy which adopts Islamic requirements for visual privacy in the housing setting as a basis and benchmark in housing design. This study focuses on terrace housing in urban areas.

\section{FINDINGS - PROPOSED CONCEPTUAL FRAMEWORK}

Optimum level of MVP is an achievement of a balance between visual restriction and visual access. It displays a scenario of ideal balance of which the familial intimacy, awrah and security of the family are well protected and at the same time enables visual access to allow the efficient provision of security, sustainability and hospitality to the family. The MVP could be complemented by elements of visual modesty to achieve this optimum level. 
Azhani Abd Manaf, Zaiton Abdul Rahim, Noor Hanita Abdul Majid, \& Spahic Omer

Towards an Islamic Application of Visual Privacy Principles on Malaysian Terrace Housing: A Conceptual Framework

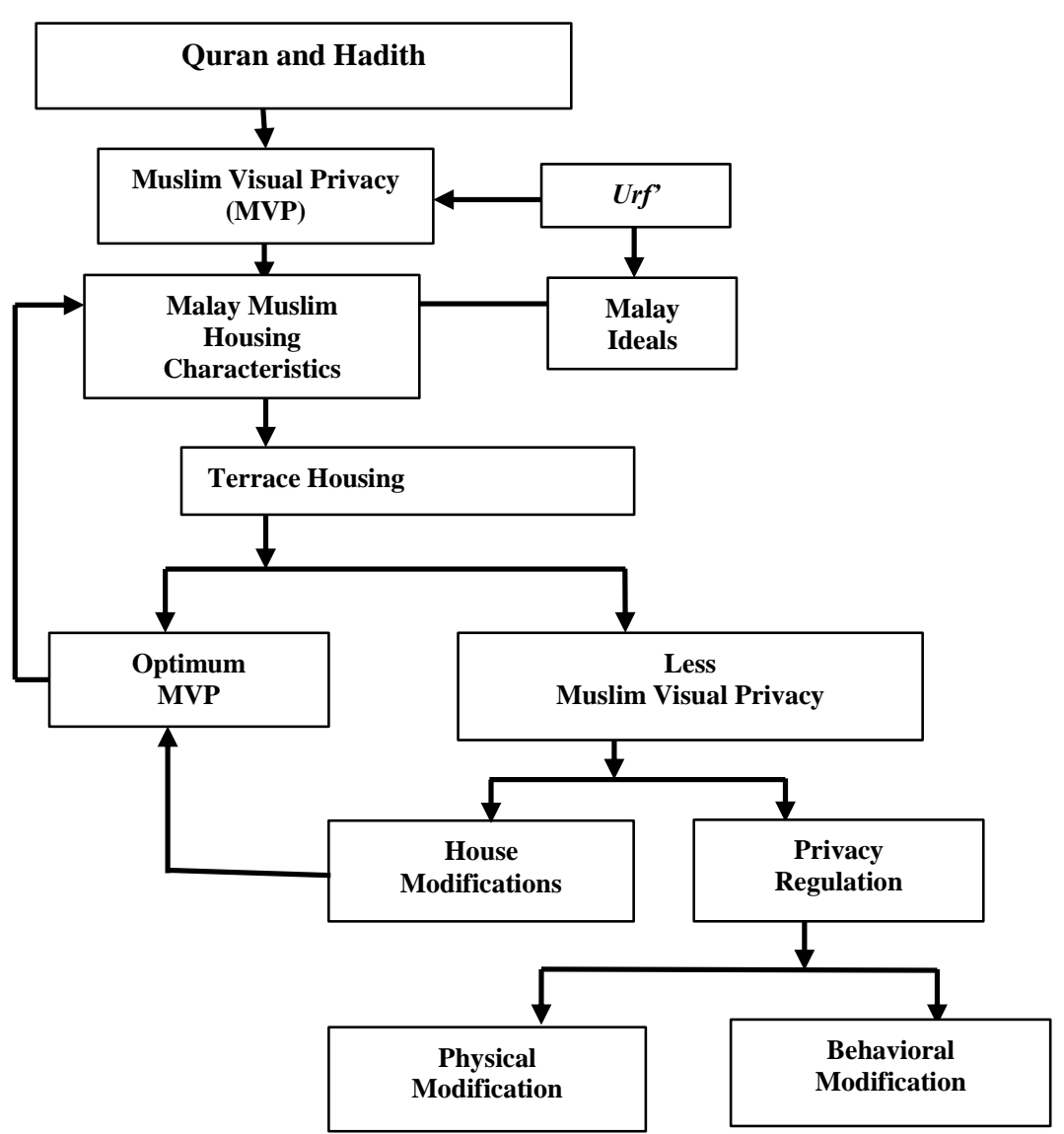

Figure 3: Proposed conceptual framework Source: Authors, 2017

Figure 3 above illustrates the dynamic system of visual privacy from Islamic perspectives. It suggests a continuous process of regulating visual privacy in order to fulfil Islamic requirements and achieve an optimum level of visual pivacy. Furthermore, it indicated that a terrace house design should be composed of Malay Muslim Housing Characteristics made up of MVP elements which are influenced by local customs ( $\left.u r f^{\prime}\right)$ and Malay ideals (priorities and perception). The final step enters an optimization process, housing modification and privacy regulations. However the MVP should be found inadequate, the cycle would repeat itself. 


\section{CONCLUSION}

Based on the findings, this paper suggests a comprehensive conceptual framework incorporating the sources of MVP elements as well as other important variables influencing the Malay Muslim occupants in terms of how they apply, regulate and modify the visual privacy levels in their respective terrace house. In Islam, the concept of closure or protecting the privacy of the family is more of a requirement instead of preference with clear outline of the importance of sanctity of the family and awrat which needs to be restricted from the view of the nonmahram (stranger) eyes. An increase in visual access with its benefits and functions is detrimental to the level of visual restriction and privacy provided to the family, and vice versa. The issue regarding prioritization and awareness of the Malay occupants themselves is a critical matter which needs further analysis. As privacy is culturally specific, there is a need for adequate knowledge and awareness regarding the right definition, principles, and rules regarding visual privacy regulations from Islamic view with regard to a specific cultural context.

\section{REFERENCES}

Abbasoglu, M. S., \& Dagli, U. U. (n.d.). Women's visual privacy analysis in traditional houses and modern apartment block neighbourhoods in Famagusta (North Cyprus). Retrieved from http://www.irbnet.de/daten/iconda/CIB16717.pdf.

Abdul Rahim, A. (2008). Housing from Islamic perspective. Kuala Lumpur: IIUM Press, Inernational Islamic University Malaysia.

Abdul Rahim, Z. (2007). Privacy and modification of terrace housing among Malay occupants in Klang Valley, Malaysia (Doctorate dissertation). Universiti Putra Malaysia, Serdang, Malaysia.

Abdul Rahim, Z., \& Hashim, A. H. (2008). The influence of privacy regulation on urban Malay families living in terrace housing. International Journal of Architectural Research: ArchNet-IJAR, 2(2), 94-102.

Abdul Rahim, Z. (2015). The influence of culture and religion on visual privacy. Procedia - Social and Behavioral Sciences, 170, 537-544.

Al-Kodmany, K. (1999). Residential visual privacy: Traditional and modern architecture and urban design. Journal of Urban Design, 4(3), 283-311.

Altman, I. (1977). Privacy regulation: Culturally universal or culturally specific? Journal of Social Issues, 33, 66-84.

Ayman N. T. (2011). Visual privacy recognition in residential areas through amendment of building regulations, urban design and planning. In Proceedings of the Institution of Civil Engineers, 1-11.

Bahammam, A. (1998). Factors which influence the size of the contemporary dwelling: Riyadh, Saudi Arabia. Habitat International, 22(4), 557-570. 
Azhani Abd Manaf, Zaiton Abdul Rahim, Noor Hanita Abdul Majid, \& Spahic Omer

Towards an Islamic Application of Visual Privacy Principles on Malaysian Terrace Housing: A Conceptual Framework

Brown, B. B., \& Altman, I. (1983). Territoriality, defensible space and residential burglary: An environmental analysis. Journal of Environmental Psychology, 3(3), 203-220.

El-Shorbagy, A. (2010). Traditional Islamic-Arab house: Vocabulary and syntax. International Journal of Civil \& Environmental Engineering, 10(04), 15-20.

Erdayu, O. O., Esmawee, E., \& Masran, S. (2010). Adapting by altering: Spatial modifications of terraced houses in the Klang Valley area. Asian Journal of Environment-Behaviour Studies, 2(2), 1-10.

Erdayu, O. O., Esmawee, E. and Masran, S. (2012). Personalisation of the Home. Procedia - Social and Behavioral Sciences, 49, 328-340.

Farah, M. Z. (2010). The Malay women and terrace housing in Malaysia (Master thesis). University of Wellington, New Zealand.

Hakim, B. S. (1994). The urf and it role in diversifying the architecture of traditional Islamic cities. Journal of Architectural and Planning Research, 11(4), 108-127.

Hakim, B. S. (2008). Arabic-Islamic cities: Building and planning principles. London: Routledge.

Kupritz, V. W. (2000). Privacy management at work: A conceptual model. Journal of Architectural and Planning Research, 17(1), 47-63.

Mortada, H. (2003). Traditional Islamic principles of built environment (1st Edition). New York: Routledge Curzon.

Newell, P. B. (1995). Perspectives on privacy. Journal of Environmental Psychology, 15, 87-104.

Noorul Huda, M. R., \& Anuar, T. (2013). The concept of privacy and the Malay dwelling interior space planning. Procedia-Social and Behavioral Sciences. http://doi.org/ 10.1016 /j.sbspro.2013.07.214

Omer, S. (2004). Studies in the Islamic built environment (2nd Edition). Kuala Lumpur: Research Center, IIUM.

Omer, S. (2010). Islam \& Housing (1st Edition). Gombak, Malaysia: A.S. Nordeen.

Ozaki, R. (2002). Housing as a reflection of culture: Privatised living and privacy in England and Japan. Housing Studies, 17(2), 209-227.

Rapoport, A. (1969). House form and culture. New Jearsey: Prentice-Hall, Inc.

Reis, A. T., \& Lay, M. C. (2004, July). Privacy in the dwelling: Attitudes, visual and functional connections. 18th IAPS-Conference Vienna, 2004. July 7-10, 2004, Vienna, Austria.

Saleh, M. A. E. (1998). The impact of Islamic and customary laws on urban form development in southwestern Saudi Arabia. Habitat International, 22(4), $537-$ 556.

Shach-Pinsly, D., Fisher-Gewirtzman, D., \& Burt, M. (2011). Visual exposure and visual openness: An integrated approach and comparative evaluation. Journal of Urban Design, 16(2), 233-256. 
PLANNING MALAYSIA

Journal of the Malaysia Institute of Planners (2018)

Sipahi, A. (2016). Window-conflicts in the Ottoman Empire and Turkey: Visual privacy, materiality and right to the city. Middle Eastern Studies, 52(4), 588-604.

Zulkeplee O., Buys, L., \& Aird, R. (2014). Observing privacy, modesty and hospitality in the home domain: Three case studies of Muslim homes in Brisbane, Australia. International Journal of Architectural Research, 8(3), 266-283. 